\title{
Modified-atmosphere Packaging of 'Heritage' Red Raspberry Fruit: Respiratory Response to Reduced Oxygen, Enhanced Carbon Dioxide, and Temperature
}

\author{
Dennis W. Joles, Arthur C. Cameron, Ahmad Shirazi ${ }^{1}$, Peter D. Petracek², \\ and Randolph M. Beaudry \\ Department of Horticulture, Michigan State University, East Lansing MI 48824-1325
}

\begin{abstract}
Additional index words. Rubus idaeus, steady-state oxygen, respiratory quotient, ethanol, anaerobic respiration, fermentation
Abstract. 'Heritage' raspberries (Rubus idaeus L. ) were sealed in low-density polyethylene packages and stored at 0 , 10, and 20C during Fall 1990 and 1991 to study respiratory responses under modified atmospheres. A range of steady-state $\mathrm{O}_{2}$ and $\mathrm{CO}_{2}$ partial pressures were achieved by varying fruit weight in packages of a specific surface area and film thickness. Film permeability to $\mathrm{O}_{2}$ and $\mathrm{CO}_{2}$ was measured and combined with surface area and film thickness to estimate total package permeability. Rates of $\mathrm{O}_{2}$ uptake and $\mathrm{CO}_{2}$ production and respiratory quotient $(\mathrm{RQ})$ were calculated using steady-state $\mathrm{O}_{2}$ and $\mathrm{CO}_{2}$ partial pressures, total package permeability, and fruit weight. The $\mathrm{O}_{2}$ uptake rate decreased with decreasing $\mathrm{O}_{2}$ partial pressure over the range of partial pressure studied. The Michaelis-Menten equation was used to model $\mathrm{O}_{2}$ uptake as a function of $\mathrm{O}_{2}$ partial pressure and temperature. The apparent $\mathrm{K}_{\mathrm{m}}\left(\mathrm{K}_{1 / 2}\right)$ remained constant $(5.6 \mathrm{kPa}$ $O_{2}$ ) with temperature, while $Q_{10}$ was estimated to be 1.9. $R Q$ was modeled as a function of $O_{2}$ partial pressure and temperature. Headspace ethanol increased at $R Q s>1.3$ to 1.5. Based on $R Q$, ethanol production, and flavor, we recommend that raspberries be stored at $\mathrm{O}_{2}$ levels above $4 \mathrm{kPa}$ at $0 \mathrm{C}, 6 \mathrm{kPa}$ at 10C, and $8 \mathrm{kPa}$ at $20 \mathrm{C}$. Steady-state $\mathrm{CO}_{2}$ partial pressures of 3 to $17 \mathrm{kPa}$ had little or no effect on $\mathrm{O}_{2}$ uptake or headspace ethanol partial pressures at $20 \mathrm{C}$.
\end{abstract}

Raspberries are a very perishable commodity, partly due to high respiration and transpiration rates, a morphology that predisposes them to crushing, and susceptibility to gray mold fruit rot. Techniques providing even a short extension of shelf life could have a profound effect on fresh-marketing raspberries. Exposing raspberries to $\mathrm{CO}_{2}$ levels of $20 \%$ or greater has been shown to delay gray mold decay and extend shelf life (Goulart et al., 1992; Smith, 1958; Winter et al., 1939). Elevated $\mathrm{CO}_{2}$ has also been shown to improve firmness of strawberries (Smith, 1992). No research has yet demonstrated a beneficial effect of reduced $\mathrm{O}_{2}$ for raspberries.

Modified-atmosphere (MA) packaging may provide suitable atmospheres to extend the shelf life of raspberries. In an MA package, steady-state package partial pressures of $\mathrm{O}_{2}\left(\left[\mathrm{O}_{2}\right]_{\mathrm{pkg}}\right)$ and $\mathrm{CO}_{2}\left(\left[\mathrm{CO}_{2}\right]_{\mathrm{pkg}}\right)$ are achieved when fruit $\mathrm{O}_{2}$ uptake and $\mathrm{CO}_{2}$ production rates are equal to the rates of $\mathrm{O}_{2}$ and $\mathrm{CO}_{2}$ flux through the film (Beaudry et al., 1992; Cameron et al., 1989).

In an MA package, $\left[\mathrm{CO}_{2}\right]_{\mathrm{pkg}}$ cannot be elevated without some reduction in $\left[\mathrm{O}_{2}\right]_{\mathrm{pkg}}$ since it is impossible to reduce the $\mathrm{CO}_{2}$ permeability of a film without also decreasing its $\mathrm{O}_{2}$ permeability. The extent of the reduction in $\mathrm{O}_{2}$ and elevation of $\mathrm{CO}_{2}$ depends on the relative $\mathrm{O}_{2}$ uptake and $\mathrm{CO}_{2}$ production rates of the fruit and the permeability of the polymer barrier to $\mathrm{O}_{2}$ and $\mathrm{CO}_{2}$. Thus, to design an MA package for raspberries with an elevated $\left[\mathrm{CO}_{2}\right]_{\mathrm{pkg}}$, it is necessary to know the $\mathrm{CO}_{2}$ production and $\mathrm{O}_{2}$ uptake rates as influenced by reduced $\mathrm{O}_{2}$ and elevated $\mathrm{CO}_{2}$ partial pressures.

When $\mathrm{O}_{2}$ around fruit falls below some critical level, there is a shift to fermentative respiration (Kader, 1986). The extent of

\footnotetext{
Received for publication 11 June 1993. Accepted for publication 15 Dec. 1993 Mention of a trademark, proprietary product, or vendor does not constitute a guarantee or warranty of the product by Michigan State Univ. and does not imply its approval over other products or vendors that may also be suitable. The cost of publishing this paper was defrayed in part by the payment of page charges. Under postal regulations, this paper therefore must be hereby marked advertisement solely to indicate this fact.

${ }^{1}$ Dept. of Food Science.

${ }^{2}$ Current address: Citrus Research and Education Center, Florida Dept. of Citrus, 700 Experiment Station Rd., Lake Alfred, FL 33850.
}

fermentative metabolism can be measured as an increase in the respiratory quotient (RQ), since ethanol production involves decarboxylation of pyruvate without $\mathrm{O}_{2}$ uptake. Burton (1978) reported that raspberries stored in $2 \%$ to $3 \% \mathrm{O}_{2}$ developed off-flavors. Beaudry et al. (1992) found that the critical $\mathrm{O}_{2}$ level for blueberries (defined as the partial pressure of $\mathrm{O}_{2}$ at which an increase in RQ was noted) increased with temperature. A description of changes in the critical lower $\mathrm{O}_{2}$ limit for raspberries with temperature has not been previously reported.

Several authors have assumed that elevated $\left[\mathrm{CO}_{2}\right]_{\text {rog }}$ affects the $\mathrm{O}_{2}$ uptake rate of fresh produce (Hayakawa et al., $1975 ;$ Henig and Gilbert, 1975; Lee et al., 1991; Song et al., 1992), although there is little evidence for this assumption. We addressed this question by generating a range of $\left[\mathrm{O}_{2}\right]_{\mathrm{pkg}}$ and $\left[\mathrm{CO}_{2}\right]_{\mathrm{pkg}}$ levels using MA packages (Beaudry et al., 1992; Cameron, 1990) and adding $\mathrm{CaO}$ as a $\mathrm{CO}_{2}$ absorber to a similar group of packages. Thus, it was possible to determine $\mathrm{O}_{2}$ uptake as a function of $\left[\mathrm{O}_{2}\right]_{\mathrm{pkg}}$ in the presence and absence of generated $\mathrm{CO}_{2}$.

The main objective of this study was to investigate the influence of $\left[\mathrm{O}_{2}\right]_{\mathrm{pkg}},\left[\mathrm{CO}_{2}\right]_{\mathrm{pkg}}$, and temperature on $\mathrm{O}_{2}$ uptake and $\mathrm{CO}_{2}$ production rates and on $\mathrm{O}_{2}$ partial pressure at the RQ breakpoint for 'Heritage' red raspberries using the technique described by Beaudry et al. (1992). Another objective of this study was to compare the respiratory behavior of fruit harvested at different times in the season.

\section{Materials and Methods}

Plant material. On 20 Sept. 1990, 15 Oct. 1990, and 9 Sept. 1991, 'Heritage' red raspberries were hand-harvested from Gibb's Farm in Onondaga, Mich., and spread three to four berries deep in coolers containing ice. A sheet of plastic film was placed over the ice to prevent direct contact. After being transported to Michigan State Univ., the fruit were sorted for consistent color and absence of defects and mold and packaged within $8 \mathrm{~h}$ of harvest.

Packaging. During Sept. 1990, fruit weights of $\approx 5,7.5,10,12.5$, $15,17.5,22.5,27.5,37.5$, and $50 \mathrm{~g}$ were sealed in packages made of 
low-density polyethylene (LDPE) (Dow Chemical, Midland, Mich.) and placed at 0 or $10 \mathrm{C}$. Fruit weights of $\approx 5,10,12.5,15,17.5,20,22.5$, $25,30,37.5$, and $45 \mathrm{~g}$ were sealed into packages placed at 20C. For packages at $0 \mathrm{C}$, film thickness was 3 mil $(76.6 \mu \mathrm{m})$ and film surface area was $300 \mathrm{~cm}^{2}(10 \times 15 \mathrm{~cm})$. For packages at 10 and $20 \mathrm{C}$, film thickness was 2 mil $(52.1 \mu \mathrm{m})$ with the same surface area.

In Oct. 1990, fruit weights of $\approx 3,5,7.5,10,12.5,17.5,22.5$, and $30 \mathrm{~g}$ were sealed into packages and placed at 10 or 20C. Surface area and thickness were the same as the September harvest. Five and six replications per target weight were used in the October and September experiments, respectively.

To reduce crushing, the fruit were placed on a $7.6 \times 12.7-\mathrm{cm}$ note card encircled by a cellulose acetate strip $(2.5 \times 30 \times 0.0508$ $\mathrm{cm})$, which prevented contact with the upper film. A gas sampling septum was attached to each package consisting of a dab of silicone sealant on a short strip of electrical tape (Boylan-Pett, 1986).

For the 1991 experiment, packages were constructed of 2-mil $(52.1-\mu \mathrm{m}) \mathrm{LDPE}$ film with a surface area of $400 \mathrm{~cm}^{2}(10 \times 20 \mathrm{~cm}$ $\times$ two sides). Target weights were $5.5,13.5,18,28$, and $48 \mathrm{~g}$, with eight replications per target weight. A $10 \times 12-\mathrm{cm}$ spunbonded polyethylene pouch (Tyvek type 1059B, Du Pont, Wilmington, Del.) was constructed containing $\mathrm{CaO}$ (98\%, Aldrich, Milwaukee) as a $\mathrm{CO}_{2}$ scrubber $(1 \mathrm{~g} \mathrm{CaO} / 10 \mathrm{~g}$ fruit). A pouch was included in a second group of packages at each weight.

Film permeability. Film permeability was measured for three film samples taken from various locations in the 2- and 3-mil rolls using the system described by Beaudry et al. (1992). Each sample was individually sealed in a permeability cell and submerged in a water bath. The permeability cell contained two chambers that were separated by the film sample. A gas mixture of $\mathrm{O}_{2}$ and $\mathrm{CO}_{2}$ was directed into one chamber and pure $\mathrm{N}_{2}$ gas was directed into the other $\left(100 \mathrm{ml} \cdot \mathrm{min}^{-1}\right)$. The appearance of $\mathrm{O}_{2}$ and $\mathrm{CO}_{2}$ was continuously monitored in the $\mathrm{N}_{2}$ stream using a sequential arrangement of $\mathrm{O}_{2}(\mathrm{~S}-3 \mathrm{~A} / \mathrm{II}$ with a calcia-zirconia electrochemical detection cell; Ametek Co., Thermox Instrument Div., Pittsburgh) and $\mathrm{CO}_{2}$ (ADC 225-Mk3; Analytical Development Co., Hertfordshire, England) analyzers. By altering water bath temperature, permeabilities were measured at $5 \mathrm{C}$ increments between 0 and 30C. Each film sample was measured over the entire temperature range three to five times.

The Arrhenius equation was used to describe permeation of gases through polymers and can be expressed as

$$
P_{i}=A_{r} \cdot \exp \left(-\frac{E_{a}}{R T}\right)
$$

where $\mathrm{P}$ is permeability to $\mathrm{O}_{2}$ or $\mathrm{CO}_{2}\left(\mathrm{mmol} \cdot \mathrm{cm}^{-1} \cdot \mathrm{cm}^{-2}\right.$ perh per $\left.\mathrm{kPa}\right)$; $\mathrm{E}_{\mathrm{a}}$ is the energy of activation of $\mathrm{O}_{2}$ or $\mathrm{CO}_{2}$ permeation $\left(\mathrm{kJ} \cdot \mathrm{mol}^{-1}\right)$; and $\mathrm{R}$ is the gas constant $\left(0.008314 \mathrm{~kJ} \cdot \mathrm{mol}^{-1} \cdot \mathrm{K}^{-1}\right)($ Pauly, 1989).

Regression analysis was performed on transformed data to estimate values of $\mathrm{E}_{\mathrm{a}}$, the Arrhenius constant $\mathrm{A}_{\mathrm{r}}$, and coefficients of determination (Table 1).

Gas analysis and respiration rate calculations. Headspace $\mathrm{O}_{2}$ and $\mathrm{CO}_{2}$ partial pressures were determined by withdrawing two 0.5-ml samples from packages using an insulin-type syringe and injecting them into an $\mathrm{N}_{2}$ gas stream (150 to $200 \mathrm{ml} \cdot \mathrm{min}^{-1}$ flow rate), which was connected to the sequential $\mathrm{O}_{2}$ and $\mathrm{CO}_{2}$ analyzers described above. Response time was $10 \mathrm{sec}$ per sample. A third sample was taken if readings for the first two samples differed.

Headspace ethanol partial pressures were determined in two 0.5-ml samples withdrawn from the package headspace using a glass syringe (0.5-ml Gastight-1750; Hamilton Co., Reno, Nev.). Gas analysis was performed on a gas chromatograph (Carle Series
100; Hach Co., Loveland, Colo.) equipped with a porous polymer column (Haysep 80/100; Alltech Assoc., Deerfield, Ill.) and a flame ionization deterctor. Column temperature was $120 \mathrm{C}$ and the flow rate of the $\mathrm{N}_{2}$ carrier gas was $100 \mathrm{ml} \cdot \mathrm{min}^{-1}$. For standards, ethanol solutions were prepared in volumetric flasks and sealed with serum caps. Peak area increased linearly with the concentration between 50 and $5000 \mathrm{ppm}$ (data not shown). The headspace partial pressure over $1000 \mathrm{ppm}$ at $22 \mathrm{C}$ was calculated to be $7.5 \mathrm{~Pa}$ (Harger et al., 1950).

Ethanol analysis of the fruit harvested in Sept. 1990 at 20C showed a large variability among replicated packages. To reduce variability in subsequent experiments, the time from sampling to analysis was minimized and needles were checked to ensure that they were not plugged with silicone from the sampling septum.

The time to reach steady-state $\mathrm{O}_{2}$ and $\mathrm{CO}_{2}$ levels was monitored in separate packages containing the lowest and highest fruit weights for each storage temperature. When no further change in $\left[\mathrm{O}_{2}\right]_{\mathrm{pkg}}$ and $\left[\mathrm{CO}_{2}\right]_{\mathrm{pkg}}$ was detected in these packages, gas analysis was performed on all packages at that temperature. All gas analyses were performed after 12 days at $0 \mathrm{C}, 7$ days at 10C, and 3 days at $20 \mathrm{C}$.

Respiration rates were calculated using the following formulae:

$$
\begin{aligned}
\mathrm{R}_{\mathrm{O}_{2}} & =\frac{\frac{\mathrm{P}_{\mathrm{O}_{2}} \cdot \mathrm{A}}{\Delta \mathrm{x}}\left(\left[\mathrm{O}_{2}\right]_{\mathrm{atm}}-\left[\mathrm{O}_{2}\right]_{\mathrm{pkg}}\right)}{\mathrm{W}} \\
\mathrm{R}_{\mathrm{CO}_{2}} & =\frac{\frac{\mathrm{P}_{\mathrm{O}_{2}} \cdot \mathrm{A}}{\Delta \mathrm{x}}\left(\left[\mathrm{CO}_{2}\right]_{\mathrm{pkg}}-\left[\mathrm{CO}_{2}\right]_{\mathrm{atm}}\right)}{\mathrm{W}}
\end{aligned}
$$

where $\mathrm{R}_{\mathrm{O}_{2}}$ and $\mathrm{R}_{\mathrm{CO}_{2}}$ are $\mathrm{O}_{2}$ uptake and $\mathrm{CO}_{2}$ production rates $\left(\mathrm{mmol} \cdot \mathrm{kg}^{-1} \cdot \mathrm{h}^{-1}\right)$, respectively; $\mathrm{P}_{\mathrm{O}_{2}}$ and $\mathrm{P}_{\mathrm{CO}_{2}}$ are permeability coef-

Table 1. Activation energies $\left(\mathrm{E}_{\mathrm{a}}\right)$, Arrhenius constants $\left(\mathrm{A}_{\mathrm{r}}\right)$, and coefficients of determination $\left(r^{2}\right)$ for 52.1- and 76.6- $\mu \mathrm{m}$ LDPE films. Values were obtained from linear transformation of data using the equation $\mathrm{P}_{\mathrm{i}}=\mathrm{A}_{\mathrm{r}} \times \exp \left(-\mathrm{E}_{\mathrm{a}} / \mathrm{RT}\right)$, where $\mathrm{P}_{\mathrm{i}}$ is permeability to $\mathrm{O}_{2}$ or $\mathrm{CO}_{2}\left(\mathrm{mmol} \cdot \mathrm{cm}^{-1} \cdot \mathrm{cm}^{-2}\right.$ per $\mathrm{h}$ per $\left.\mathrm{kPa}\right), \mathrm{E}_{\mathrm{a}}$ is the activation energy of $\mathrm{O}_{2}$ or $\mathrm{CO}_{2}$ permeation $\left(\mathrm{kJ} \cdot \mathrm{mol}^{-1}\right)$, and $\mathrm{R}$ is the gas constant $\left(0.008314 \mathrm{~kJ} \cdot \mathrm{mol}^{-1} \cdot \mathrm{K}^{-1}\right)$ (Pauly, 1989).

\begin{tabular}{lcccc}
\hline \hline $\begin{array}{l}\text { Film } \\
\text { thickness } \\
(\mu \mathrm{m})\end{array}$ & Variable & $\begin{array}{c}\mathrm{E}_{\mathrm{a}} \\
\left(\mathrm{kJ} \cdot \mathrm{mol}^{-1}\right)\end{array}$ & $\mathrm{A}_{\mathrm{r}}$ & $r^{2}$ \\
\hline 52.1 & $\mathrm{P}_{\mathrm{O}_{2}}$ & 38.1 & 0.131 & 0.945 \\
52.1 & $\mathrm{P}_{\mathrm{CO}_{2}}$ & 35.6 & 0.218 & 0.957 \\
76.6 & $\mathrm{P}_{\mathrm{O}_{2}}$ & 36.7 & 0.700 & 0.968 \\
76.6 & $\mathrm{P}_{\mathrm{CO}_{2}}$ & 35.3 & 0.177 & 0.971 \\
\hline
\end{tabular}

Table 2. Whole-package $\mathrm{O}_{2}$ and $\mathrm{CO}_{2}$ permeabilities $\left(\mathrm{P}_{\mathrm{O}_{2}} \times \mathrm{A} / \Delta \mathrm{x}\right.$ and $\mathrm{P}_{\mathrm{CO}_{2}}$ $\times \mathrm{A} / \Delta \mathrm{x}$, respectively) for the packages used in these experiments at 0 , 10, and 20C. Appropriate values were substituted into Eqs. [2 and 3] to calculate $\mathrm{O}_{2}$ uptake and $\mathrm{CO}_{2}$ production for fruit at 0,10 , or $20 \mathrm{C}$.

\begin{tabular}{lccc}
\hline \hline \multirow{2}{*}{$\begin{array}{l}\text { Temp } \\
\left({ }^{\circ} \mathrm{C}\right)\end{array}$} & $\mathrm{P}_{\mathrm{O}_{2}} \times \mathrm{A} / \Delta \mathrm{x}$ & $\mathrm{P}_{\mathrm{CO}_{2}} \times \mathrm{A} / \Delta \mathrm{x}$ & \\
\cline { 2 - 3 } & \multicolumn{1}{c}{$\left(\mathrm{mmol} \cdot \mathrm{h}^{-1} \cdot \mathrm{kPa}^{-1}\right)$} & $\mathrm{P}_{\mathrm{CO}_{2}} / \mathrm{P}_{\mathrm{O}_{2}}$ \\
\hline 0 & $2.44 \times 10^{-4}$ & $1.20 \times 10^{-3}$ & 4.91 \\
10 & $6.97 \times 10^{-4}$ & $3.44 \times 10^{-3}$ & 4.94 \\
20 & $12.11 \times 10^{-4}$ & $5.77 \times 10^{-3}$ & 4.76 \\
\hline
\end{tabular}


ficients for $\mathrm{O}_{2}$ and $\mathrm{CO}_{2}\left(\mathrm{mmol} \cdot \mathrm{cm}^{-1} \cdot \mathrm{cm}^{-2}\right.$ per h per $\left.\mathrm{kPa}\right)$, respectively; $\mathrm{A}$ is film area $\left(\mathrm{cm}^{2}\right) ; \Delta \mathrm{x}$ is film thickness $(\mathrm{cm}) ;\left[\mathrm{O}_{2}\right]_{\mathrm{atm}}$ and $\left[\mathrm{O}_{2}\right]_{\mathrm{pkg}}$ are atmospheric and package $\mathrm{O}_{2}$ partial pressures $(\mathrm{kPa})$, respectively; $\left[\mathrm{CO}_{2}\right]_{\mathrm{pkg}}$ and $\left[\mathrm{CO}_{2}\right]_{\mathrm{atm}}$ are package and atmospheric $\mathrm{CO}_{2}$ partial pressures $(\mathrm{kPa})$, respectively; and $\mathrm{W}$ is fruit weight (kg) (Beaudry et al., 1992). Values of $\mathrm{P}_{\mathrm{O}_{2}} \times \mathrm{A} / \Delta \mathrm{x}$ and $\mathrm{P}_{\mathrm{CO}_{2}} \times \mathrm{A} / \Delta \mathrm{x}$ at 0,10 , and $20 \mathrm{C}$ are given in Table 2.

The relationship of $\mathrm{O}_{2}$ uptake to $\left[\mathrm{O}_{2}\right]_{\mathrm{pkg}}$ and temperature was fitted using the Michaelis-Menten equation:

$$
\mathrm{R}_{\mathrm{O}_{2}}=\frac{\mathrm{V}_{\mathrm{max}} \cdot\left[\mathrm{O}_{2}\right]_{\mathrm{pkg}}}{\mathrm{K}_{1 / 2}+\left[\mathrm{O}_{2}\right]_{\mathrm{pkg}}}
$$

$\mathrm{K}_{1 / 2}$ in this equation was substituted for the standard $\mathrm{K}_{\mathrm{m}}$ notation because this estimate is an apparent $\mathrm{K}_{\mathrm{m}}$ of the entire fruit that also takes into account skin resistance to gas diffusion and perhaps other factors.

$\mathrm{V}_{\max }$ was modeled as a function of $\mathrm{T}$ using the $\mathrm{Q}_{10}$ concept:

$$
\mathrm{V}_{\max }=\mathrm{R}_{\mathrm{O}_{2}}^{\max , 0} \cdot \mathrm{Q}_{10}^{\mathrm{T} / 10}
$$

where $\mathrm{R}_{\mathrm{O}_{2}}{ }^{\max , 0}$ is the maximum $\mathrm{O}_{2}$ uptake at $0 \mathrm{C}$ and $\mathrm{T}$ is temperature in ${ }^{\circ} \mathrm{C}$.

Substituting Eq. [5] into Eq. [4] yielded

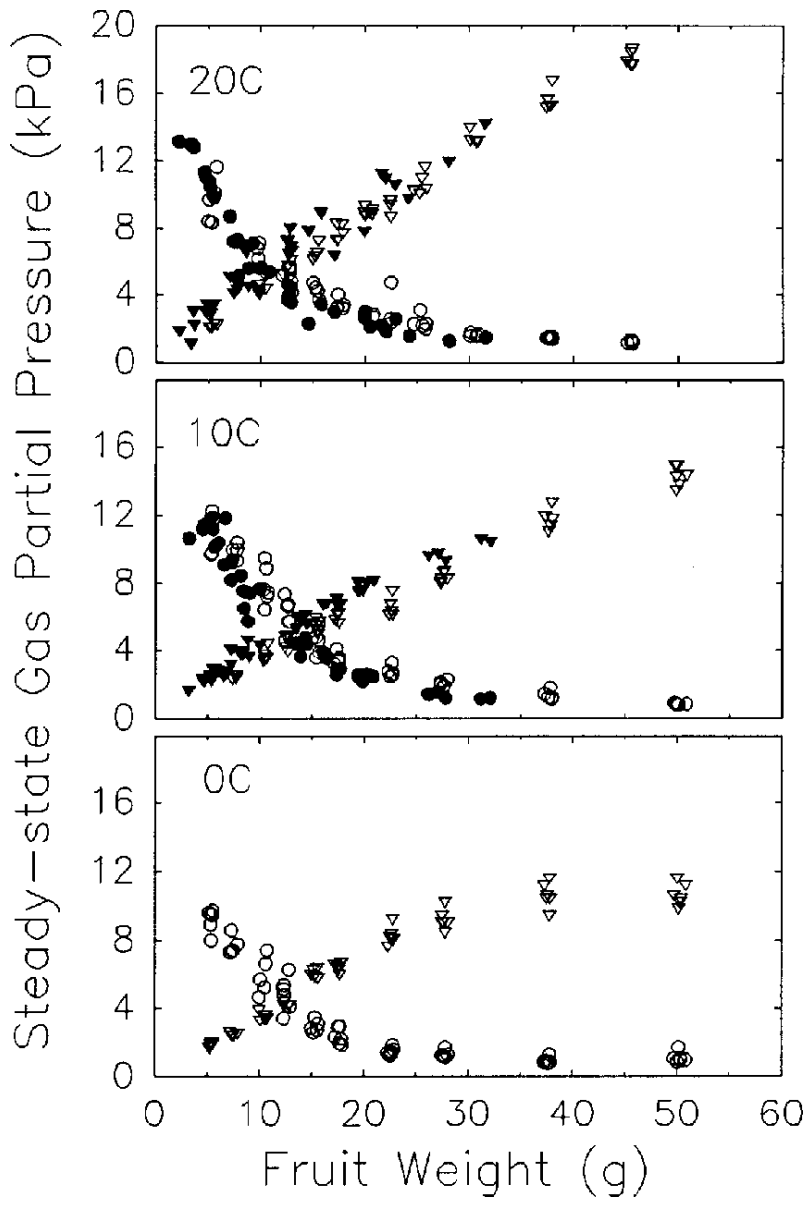

Fig. 1. Effect of raspberry fruit weight on steady-state $\mathrm{O}_{2}$ (circles) and $\mathrm{CO}_{2}$ (triangles) partial pressures for September- (open symbols) and October- (closed symbols) harvested raspberries sealed in LDPE packages where $\mathrm{A}=300 \mathrm{~cm}^{2}, \Delta \mathrm{x}$ $=52.1 \mu \mathrm{m}$ for packages at 10 and $20 \mathrm{C}$, and $\mathrm{A}=300 \mathrm{~cm}^{2}, \Delta \mathrm{x}=76.6 \mu \mathrm{m}$ for packages stored at $0 \mathrm{C}$.

$$
\mathrm{R}_{\mathrm{O}_{2}}=\frac{\mathrm{R}_{\mathrm{O}_{2}}^{\mathrm{max}, 0} \cdot \mathrm{Q}_{10}^{\mathrm{T} / 10} \cdot\left[\mathrm{O}_{2}\right]_{\mathrm{pkg}}}{\mathrm{K}_{1 / 2}+\left[\mathrm{O}_{2}\right]_{\mathrm{pkg}}}
$$

A nonlinear regression analysis to estimate the values of $\mathrm{K}_{1 / 2}$, $\mathrm{Q}_{10}$, and $\mathrm{R}_{\mathrm{O}_{2}}{ }^{\text {max,0}}$ was conducted using SAS (SAS Institute, 1989) software using the data set from the September-harvested fruit at 0,10 , and $20 \mathrm{C} . \mathrm{K}_{1 / 2}$ was originally modeled to change as a function of temperature, but regression analysis revealed that it was constant over the temperatures studied.

The RQ was calculated as $\mathrm{R}_{\mathrm{CO}_{2}} / \mathrm{R}_{\mathrm{O}_{2}}$. The relationship between $\mathrm{RQ}$, steady-state $\mathrm{O}_{2}$, and temperature was fitted with the model

$$
\mathrm{RQ}=\frac{\mathrm{q} \cdot \exp (\mathrm{rT})}{\left[\mathrm{O}_{2}\right]_{\mathrm{pkg}}}+1
$$

Nonlinear regression analysis was conducted using SAS software to estimate the values of $\mathrm{q}$ and $\mathrm{r}$. Eq. [7] was derived empirically and was found to fit the data reasonably.

Nopostharvest fungicide treatments were used on these fruit. Data was not taken from packages with obvious holes or moldy fruit.

\section{Results}

Steady-state $\mathrm{O}_{2}, \mathrm{CO}_{2}$, and respiration rates. Increasing fruit weight in a package decreased steady-state $\mathrm{O}_{2}$ and increased

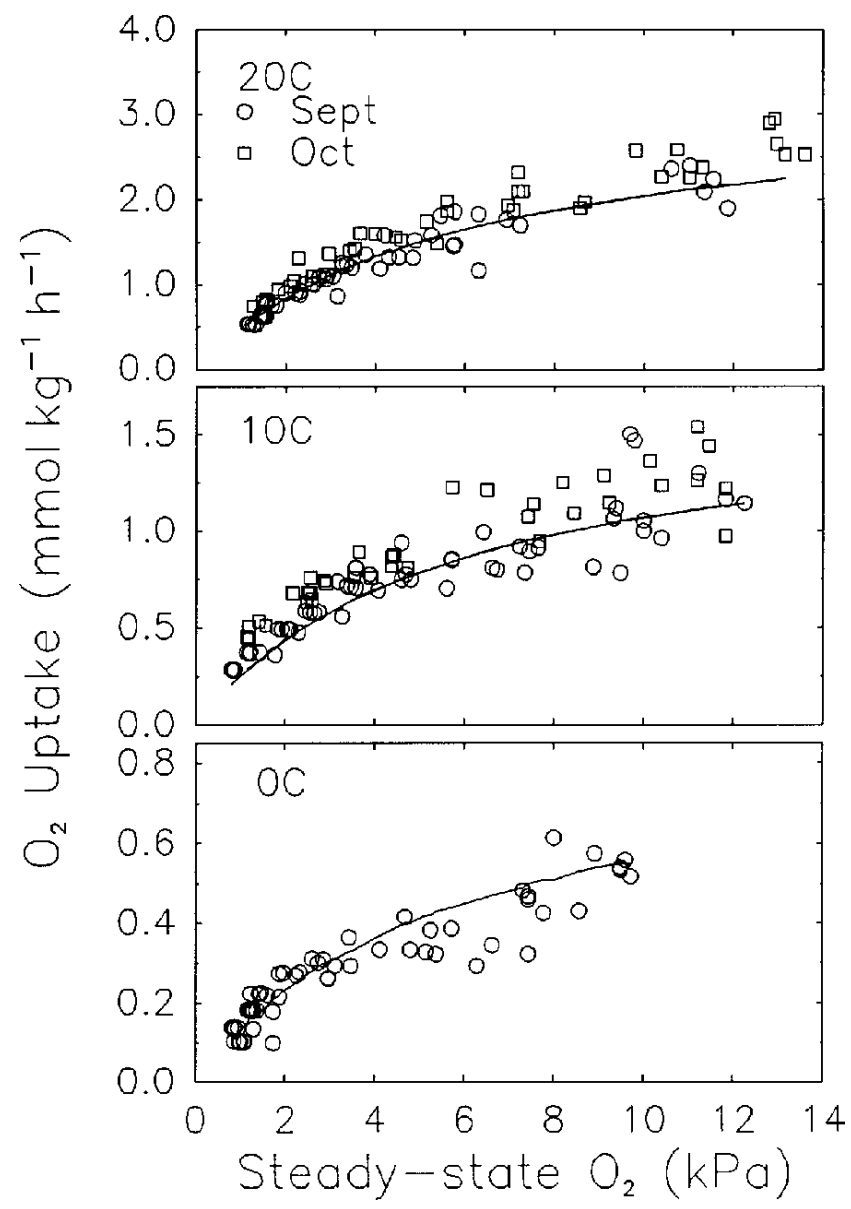

Fig. 2. Interdependent effects of steady-state $\mathrm{O}_{2}$ partial pressures and storage temperature on the calculated rate of $\mathrm{O}_{2}$ uptake for September- $(\mathrm{O})$ and October(口) harvested raspberries sealed in LDPE packages. See Eq. [6] and Table 3 for the equations and constants describing the curves. 
steady-state $\mathrm{CO}_{2}$ at 0,10 , and $20 \mathrm{C}$ (Fig. 1) and resulted in a range in $\left[\mathrm{O}_{2}\right]_{\mathrm{pkg}}$ from $<1$ to $10 \mathrm{kPa}$ at $0 \mathrm{C}$ and 1 to $12 \mathrm{kPa}$ at 10 and $20 \mathrm{C}$. Steady-state $\left[\mathrm{CO}_{2}\right]_{\mathrm{pkg}}$ ranged from 1 to $10 \mathrm{kPa}$ at $0 \mathrm{C}, 1$ to $13 \mathrm{kPa}$ at $10 \mathrm{C}$, and 1 to $14 \mathrm{kPa}$ at $20 \mathrm{C}$. The range of $\mathrm{O}_{2}$ at each fruit weight indicates the variability in $\left[\mathrm{O}_{2}\right]_{\mathrm{pkg}}$, which is expected as a consequence of variability in respiration.

A decrease in $\left[\mathrm{O}_{2}\right]_{\mathrm{pkg}}$ slowed $\mathrm{R}_{\mathrm{O}_{2}}$ (Fig. 2) at all temperatures. $\mathrm{K}_{1 /}$ ${ }_{2}$ was $5.59 \pm 0.40 \mathrm{kPaO}_{2}$ and was constant with temperature. $\mathrm{R}_{\mathrm{O}_{2}}{ }_{\text {max }, 0}$ was estimated to be $0.872 \pm 0.04 \mathrm{mmol} \cdot \mathrm{kg}^{-1} \cdot \mathrm{h}^{-1}$ and $\mathrm{Q}_{10}$ was estimated to be $1.92 \pm 0.06$. $\mathrm{R}_{\mathrm{O}_{2}}$ of the October-harvested fruit was consistently higher than that of the September-harvested fruit (Fig. 2 ), although the differences were not significant.

The RQ increased gradually as $\left[\mathrm{O}_{2}\right]_{\mathrm{pkg}}$ decreased from 10 to 6 $\mathrm{kPa}$ and climbed more rapidly at lower $\left[\mathrm{O}_{2}\right]_{\mathrm{pkg}}$ levels (Fig. 3). RQ varied with $\left[\mathrm{O}_{2}\right]_{\mathrm{pkg}}$ as follows:

$$
\mathrm{RQ}=\frac{1.43 \cdot \exp (0.053 \mathrm{~T})}{\left[\mathrm{O}_{2}\right]_{\mathrm{pkg}}}+1
$$

$\mathrm{R}_{\mathrm{CO}_{2}}$ as a function of $\left[\mathrm{O}_{2}\right]_{\mathrm{pkg}}$ can be calculated by multiplying the equation for RQ ([Eq. 8]) by the equation for $\mathrm{O}_{2}$ uptake ([Eq. 6]).

Headspace ethanol partial pressures followed a trend similar to

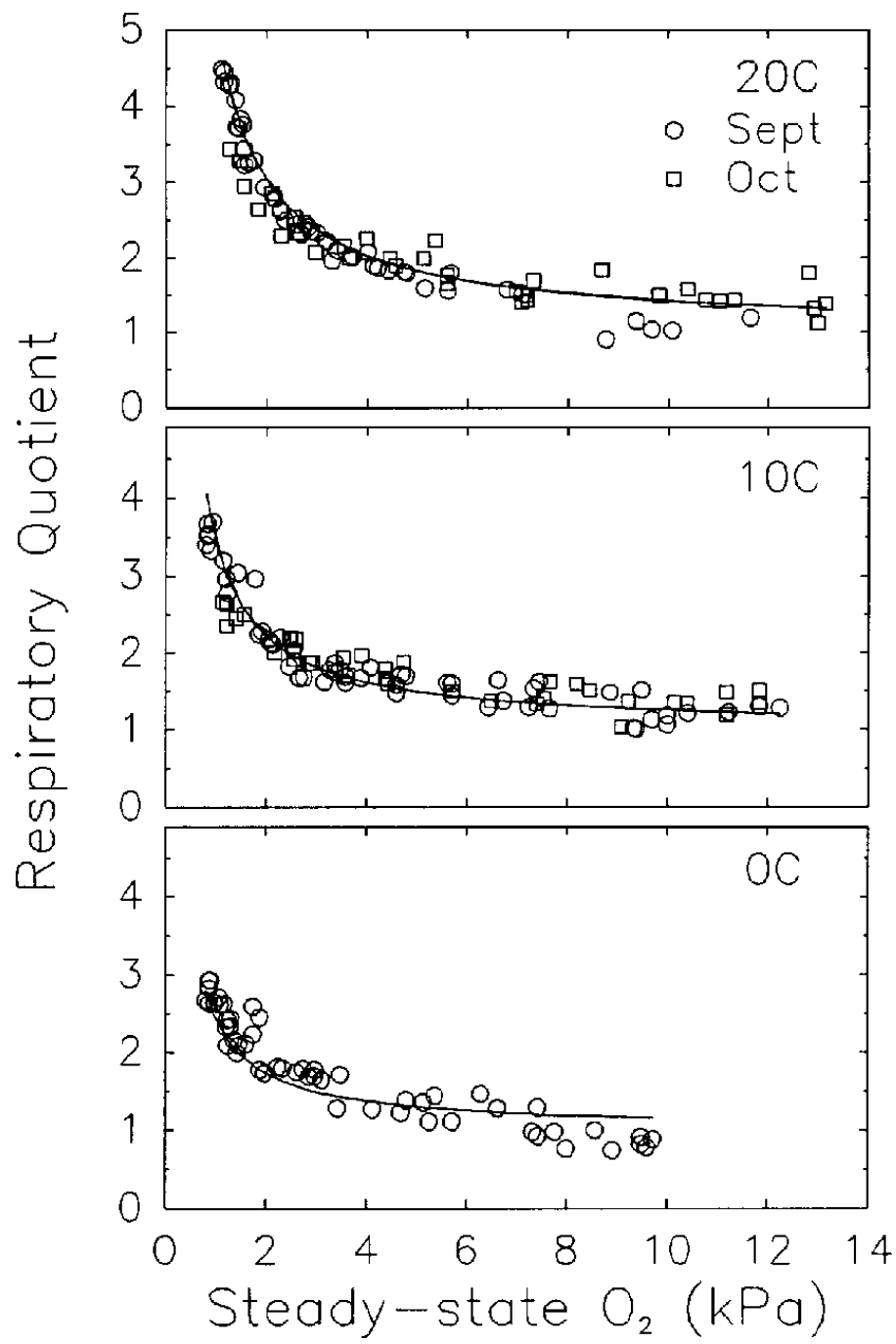

Fig. 3. Effect of steady-state $\mathrm{O}_{2}$ partial pressure and storage temperature on the respiratory quotient of September- $(O)$ and October- $(\square)$ harvested raspberries sealed in LDPE packages. See Eq. [8] for the equation and constants describing the curves.
RQ (Figs. 3 and 4). For each harvest and temperature, headspace ethanol was relatively low at $R Q$ s below $\approx 1.3$ and increased at $R Q s$ $>1.3$ to 1.5 (Fig. 5). September-harvested fruit at 20C had highly variable headspace ethanol partial pressures (Figs. 4 and 5), which may have been due in part to sampling errors (see Materials and Methods ).

Packages with and without $\mathrm{CaO}$. In packages containing $\mathrm{CaO}$, $\left[\mathrm{CO}_{2}\right]_{\mathrm{pkg}}$ was $0.1 \mathrm{kPa}$ or less, while in packages without $\mathrm{CaO}$, $\left[\mathrm{CO}_{2}\right]_{\mathrm{pkg}}^{\mathrm{pkg}}$ ranged from 3 to $17 \mathrm{kPa}$ (Fig. 6). $\left[\mathrm{O}_{2}\right]_{\mathrm{pkg}}$ was essentially the same for packages with and without $\mathrm{CaO}$ (Fig. 6). The $\mathrm{K}_{1 / 2}$ s for $\mathrm{O}_{2}$ uptake were $4.09(\mathrm{SE} \pm 0.84)$ and $4.31(\mathrm{SE} \pm 0.60) \mathrm{kPa} \mathrm{O}_{2}$ for packages with and without $\mathrm{CaO}$, respectively. $\mathrm{R}_{\mathrm{O}_{2}}{ }_{2}$ ax values $\left(\mathrm{O}_{2}\right.$ uptake $\left.\mathrm{mmol} \cdot \mathrm{kg}^{-1} \cdot \mathrm{h}^{-1}\right)$ were $3.09(\mathrm{SE} \pm 0.26)$ and $3.62(\mathrm{sE} \pm 0.22)$ for packages with and without $\mathrm{CaO}$, respectively. These were not significantly different at the $95 \%$ confidence level. Headspace ethanol vapor was also similar for packages with and without $\mathrm{CaO}$ (Fig. 6), and there was no evidence to suggest that the presence of $\mathrm{CO}_{2}$ caused a change in the critical lower $\mathrm{O}_{2}$ limit.

\section{Discussion}

The effect of elevated $\mathrm{CO}_{2}$ partial pressure on the respiration

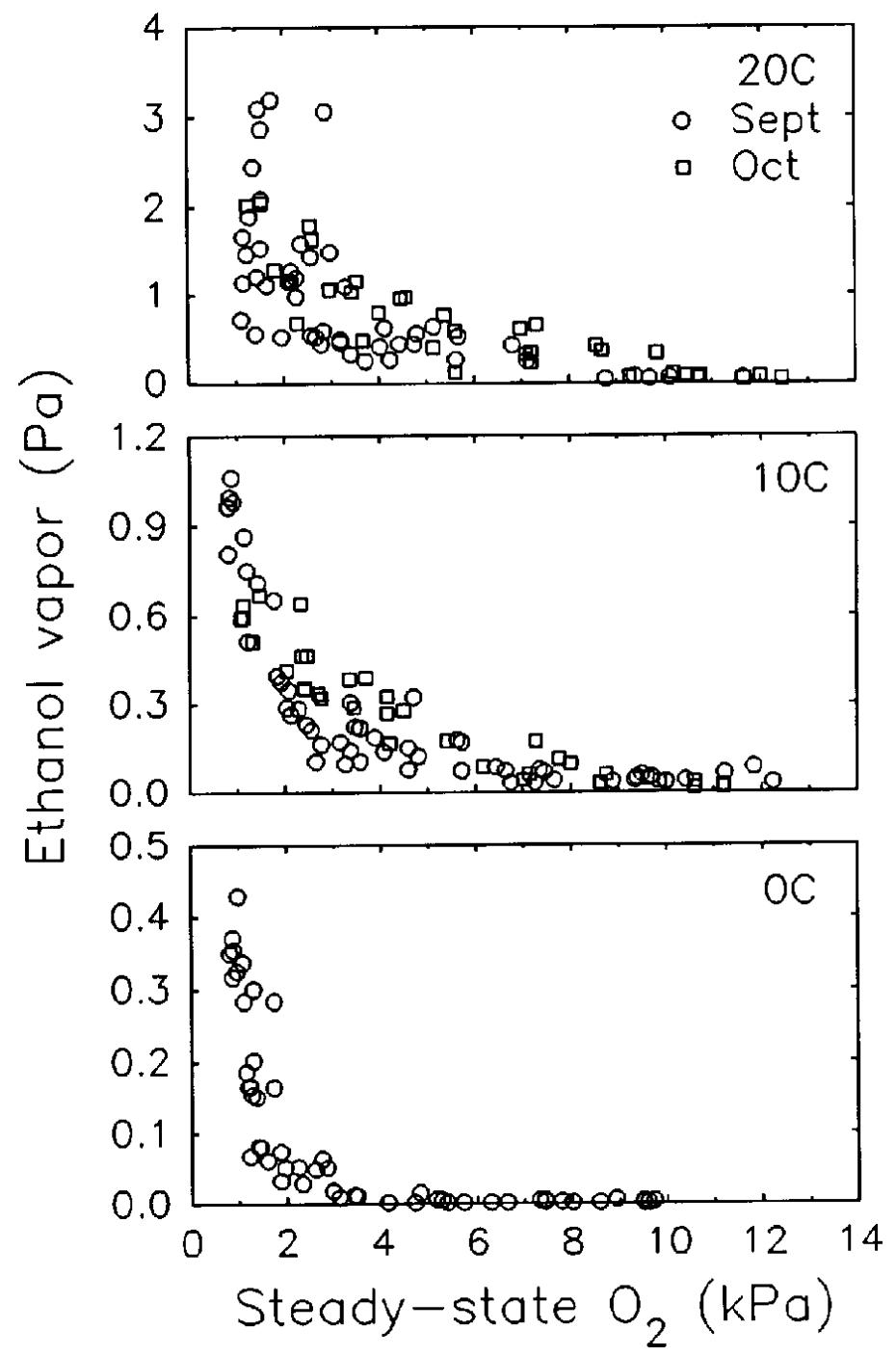

Fig. 4. Interdependent effects of steady-state $\mathrm{O}_{2}$ partial pressure and storage temperature on headspace ethanol vapor partial pressure for September- $(\bigcirc)$ and October- $(\square)$ harvested raspberries sealed in LDPE packages. Note that $1 \mathrm{~Pa} \approx 10$ $\mu 1 \cdot$ liter ${ }^{-1}$. Ethanol was measured after 12 days at $0 \mathrm{C}, 7$ days at $10 \mathrm{C}$, and 3 days at 20C. 
rate of a fruit or vegetable depends on the commodity and level of CO used (Kidd, 1916; Kubo et al., 1990; Mangin, 1896; Thornton, 1933). Some general models describing $\mathrm{O}_{2}$ uptake of fresh produce in MA atmospheres have been based in part on the assumption that elevating $\mathrm{CO}_{2}$ partial pressure to any level will inhibit $\mathrm{O}_{2}$ uptake (Hayakawa et al., 1975; Henig and Gilbert, 1975; Lee et al., 1991; Song et al., 1992). Elevated $\mathrm{CO}_{2}$ has been reported to reduce $\mathrm{O}_{2}$ uptake in some climacteric fruit (Kerbel et al., 1988; Kubo et al., 1990; Young et al., 1962). For raspberries, there was no evidence that $\mathrm{CO}_{2}$ partial pressures of 3 to $17 \mathrm{kPa}$ altered the $\mathrm{O}_{2}$ uptake rate (Fig. 6). The $\mathrm{O}_{2}$ uptake rates of blueberries and grapes have been shown to be unaffected by $\mathrm{CO}_{2}$ partial pressures up to $20 \mathrm{kPa}$ (R.M. Beaudry, 1993; Kubo et al., 1990). We found that an elevated $\mathrm{CO}_{2}$ of $20 \mathrm{kPa}$ had little if any effect on $\mathrm{O}_{2}$ uptake by 'Heritage' red raspberries in reduced- $\mathrm{O}_{2}$ atmospheres (unpublished data). Thus, $\mathrm{O}_{2}$ uptake by raspberries in our MA packages could be described as a function of $\mathrm{O}_{2}$ partial pressure and temperature only ([Eq. 6]).

Beaudry et al. (1992) found that the anaerobic RQ breakpoint was sharply defined for blueberries and, on this basis, they were able to identify lower $\mathrm{O}_{2}$ limits as a function of temperature. For raspberries, RQ increased gradually with decreasing $\mathrm{O}_{2}$, which made it difficult to define a clear lower $\mathrm{O}_{2}$ limit based on $\mathrm{RQ}$ breakpoint (Figs. 3 and 4). In addition, RQ of aerobic fruit at $0 \mathrm{C}$ was $\approx 1.0$, whereas, at 10 and $20 \mathrm{C}$, aerobic fruit had an RQ of $\approx 1.3$ (Fig. 3). Ethanol production also increased gradually with decreas-

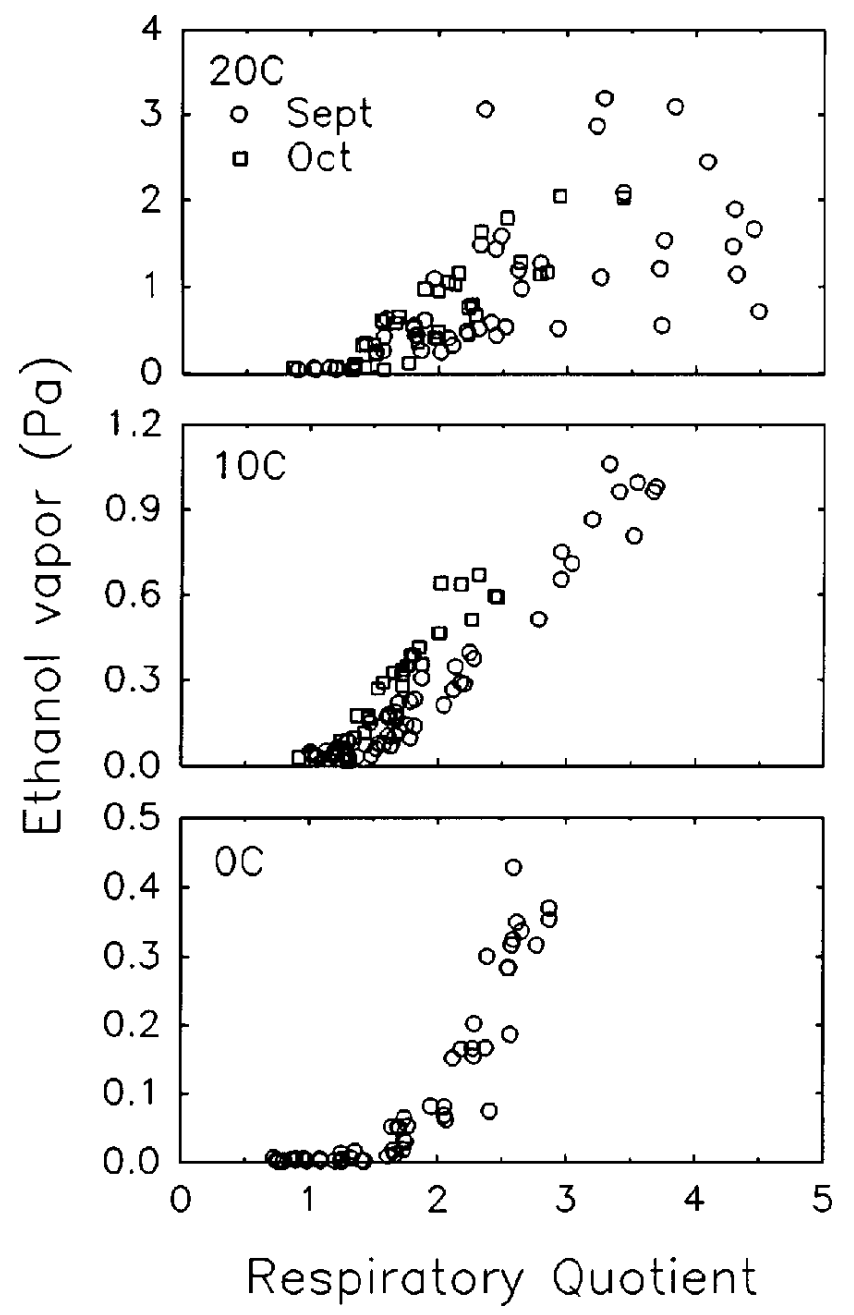

Fig. 5. Relationship of headspace ethanol vapor partial pressure and the respiratory quotient measured for September- $(\bigcirc)$ and October- $(\square)$ harvested raspberries sealed in LDPE packages and stored at 0, 10, and 20C. ing $\mathrm{O}_{2}$ at 10 and $20 \mathrm{C}$ with no clear breakpoint (Fig. 4). At 0C, ethanol production increased relatively sharply as $\mathrm{O}_{2}$ fell below 3 $\mathrm{kPa}$. In general, ethanol production did not increase substantially until the RQ rose above 1.3 to 1.5 (Fig. 5), which approximately corresponded to $\mathrm{O}_{2}$ levels of 3 to $4 \mathrm{kPa}$ at $0 \mathrm{C}, 5$ to $6 \mathrm{kPa}$ at $10 \mathrm{C}$, and 6 to $8 \mathrm{kPa}$ at $20 \mathrm{C}$ (Fig. 3).

RQ levels $>1.0$ without substantial ethanol production may have been due to the use of organic acids as the primary respiratory substrate or localized fermentation combined with partial ethanol metabolism. The correlation between RQ, headspace ethanol, and decreasing $\mathrm{O}_{2}$ observed at 10 and 20C (Figs. 3-5) supports the latter explanation, while at $0 \mathrm{C}$, the gradual increase in RQ contrasted with the sharp break in ethanol production (Fig. 5) may indicate that organic acid oxidation results in an RQ increase up to a level of $\approx 1.3$.

In informal taste tests, we noted off-flavors when $\mathrm{O}_{2}$ levels fell below $\approx 3 \mathrm{kPa}$ at $0 \mathrm{C}$ and $\approx 5 \mathrm{kPa}$ at 10 and $20 \mathrm{C}$. This approximately correlated with the $\mathrm{O}_{2}$ partial pressure at which RQ exceeded 1.3 to 1.5 at each temperature. We recommend, based on $R Q$, ethanol
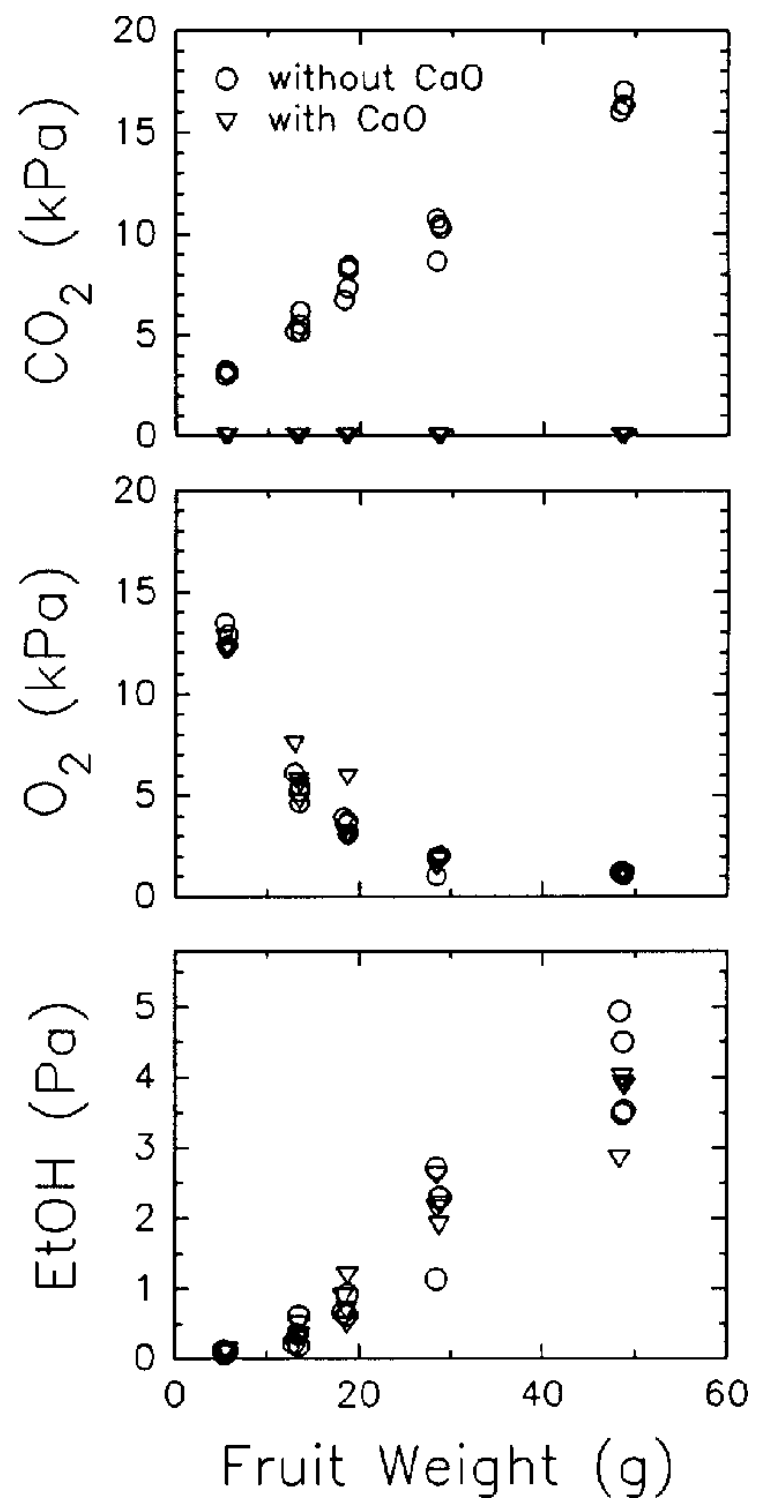

Fig. 6. Effect of raspberry fruit weight on steady-state $\mathrm{O}_{2}$ and $\mathrm{CO}_{2}$ partial pressures and on headspace ethanol vapor partial pressure in sealed packages with $(\nabla)$ and without (O) $\mathrm{CaO}$ where $\mathrm{A}=400 \mathrm{~cm}^{2}$ and $\Delta \mathrm{x}=52.1 \mu \mathrm{m}$ LDPE. Packages were held at $20 \mathrm{C}$. 
production, and flavor, that raspberries be held at $\mathrm{O}_{2}$ levels above 4 $\mathrm{kPa}$ at $0 \mathrm{C}, 6 \mathrm{kPa}$ at $10 \mathrm{C}$, and $8 \mathrm{kPa}$ at $20 \mathrm{C}$ to avoid fermentative induction and off-flavors. It should be noted that raspberries are very sensitive to reduced $\mathrm{O}_{2}$ levels. For instance, the fermentative induction point for blueberries at $0 \mathrm{C}$ was found to be $0.5 \mathrm{kPa}$ (Beaudry et al., 1992), whereas it was not $<3 \mathrm{kPa}$ for raspberries at $0 \mathrm{C}$.

In packages with and without a $\mathrm{CO}_{2}$ scrubber, headspace ethanol partial pressures as a function of $\mathrm{O}_{2}$ partial pressures were very similar (Fig. 6), which indicates that fermentative induction was not influenced by the elevated $\mathrm{CO}_{2}$ levels generated in these packages.

It has been reported that an atmosphere of $\approx 20 \mathrm{kPa} \mathrm{CO}_{2}$ retards molds and extends shelf life of raspberries (Goulart et al., 1992; Smith, 1958; Winter et al., 1939). Mold development was retarded for at least 1 day in packages with $\mathrm{CO}_{2}$ partial pressures $>15 \mathrm{kPa}$ (data not shown). However, using LDPE film, $\mathrm{O}_{2}$ levels at these $\mathrm{CO}_{2}$ partial pressures caused fermentation (Figs. 1 and 3). All polymer films have a higher permeability to $\mathrm{CO}_{2}$ than to $\mathrm{O}_{2}$ (Pauly, 1989). Thus, using polymer films, beneficial CO $\mathrm{CO}_{2}$ levels $(\approx 20 \mathrm{kPa})$ cannot be reached without inducing fermentation. There was no evidence to suggest that reduced $\mathrm{O}_{2}$ caused an extension in the shelf life of raspberries (data not shown). Oxygen diffuses $\approx 30 \%$ faster than $\mathrm{CO}_{2}$ in air, which implies that the permeability of a perforation to $\mathrm{O}_{2}$ is 1.3 times higher than its permeability to $\mathrm{CO}_{2}$ (Nobel, 1991). If a package were designed by selecting an appropriately sized perforation to maintain $10 \mathrm{kPa} \mathrm{O}_{2}$, and if $\mathrm{RQ}$ were $\approx 1.3$, then $18 \mathrm{kPaCO}_{2}$ could be generated at steady state. However, permeation through a hole changes relatively little with temperature, while $\mathrm{O}_{2}$ uptake by raspberries approximately doubles with a $10 \mathrm{C}$ increase $\left(\mathrm{Q}_{10}=1.9\right)$. Thus, fermentative conditions could develop if perforated packages experienced an increase in temperature. These are factors that will need to be incorporated into an effective MA package system designed for raspberries.

\section{Literature Cited}

Beaudry, R.M. 1993. Effect of carbon dioxide partial pressure on blueberry fruit respiration and respiratory quotient. Postharvest Biol. Technol. 3:249-254.

Beaudry, R.M., A.C. Cameron, A. Shirazi, and D.L. Dostal-Lange. 1992. Modified atmosphere packaging of blueberry fruit: Effect of temperature on package $\mathrm{O}_{2}$ and $\mathrm{CO}_{2}$. J. Amer. Soc. Hort. Sci. 117:436-441.

Boylan-Pett, W. 1986. Design and function of a modified atmosphere package for tomato fruit. MS thesis. Michigan State Univ., East Lansing.

Burton, W.G. 1978. Biochemical and physiological effects of modified atmospheres and their role in quality maintenance, p. 97. In: H.O. Hultin and M. Milner (eds.). Post-harvest biology and biotechnology. Food and Nutrition Press, Westport, Conn.

Cameron, A.C. 1990. Modified atmosphere packaging: A novel approach for optimizing package oxygen and carbon dioxide. Proc. 5th Intl. Controlled Atmosphere Conf., 14-16 June, Wenatchee, Wash.

Cameron, A.C., W. Boylan-Pett, and J. Lee. 1989. Design of modified atmosphere packaging systems: Modeling oxygen concentrations within sealed packages of tomato fruits. J. Food Sci. 54:1413-1416, 1421.

Goulart, B.L., P.E. Hammer, K.B. Evensen, W. Janisiewcz, and F. Takeda. 1992. Pyrrolnitrin, Captan + Benomyl, and high $\mathrm{CO}_{2}$ enhance raspberry shelf life at 0 or 18C. J. Amer. Soc. Hort. Sci. 117:265-270.

Harger, R.N., B.B. Raney, E.G. Birdwell, and M.F. Kitchel. 1950. The partition ratio of alcohol between air and water, urine and blood; estimation and identification of alcohol in these liquids from analysis of air equilibrated with them. J. Biol. Chem. 183:197-213.

Hayakawa, K., Y.S. Henig, and S.G. Gilbert. 1975. Formulae for predicting gas exchange of fresh produce in polymeric film package. J. Food Sci. 40:186-191.

Henig Y.S. and S.G. Gilbert. 1975. Computer analysis of the variables affecting respiration and quality of produce packaged in polymeric films. J. Food Sci. 40:1033-1036.

Kader, A.A. 1986. Biochemical and physiological basis for effects of controlled and modified-atmospheres on fruits and vegetables. Food Technol. 40(5):99-104.

Kerbel, E.L., A.A. Kader, and R.J. Romani. 1988. Effects of elevated $\mathrm{CO}_{2}$ concentrations on glycolysis in intact 'Bartlett' pear fruit. Plant Physiol. 86:1205-1209.

Kidd, F. 1916. The controlling influence of carbon dioxide. III. The retarding effect of carbon dioxide on respiration. Proc. Royal Soc. (London) 89:136-156.

Kubo Y., A. Inaba, and R. Nakamura. 1990. Respiration and $\mathrm{C}_{2} \mathrm{H}_{4}$ production in various harvested crops held in $\mathrm{CO}_{2}$-enriched atmospheres. J. Amer. Soc. Hort. Sci. 115:975-978.

Lee, D.S., P.E. Haggar, J. Lee, and K.L. Yam. 1991. Model for fresh produce respiration in modified atmospheres based on principles of enzyme kinetics. J. Food Sci. 56:1580-1585.

Mangin, L. 1896. Sur la vegetation dans une atmosphere viciee par 1 a respiration. Compt. Rend. Acad. Sci. (Paris) 122:747-749.

Mason, D.T. 1974. Measurement of fruit ripeness and its relation to mechanical harvesting of the red raspberry (Rubus idaeus L.). Hort. Res. 14:21-27.

Nobel, P.S. 1991. Physicochemical and environmental plant physiology. Academic Press, San Diego.

Pauly, S. 1989. Polymer handbook IV. 3rd ed. Wiley, New York. p. 435449.

Robbins, J., T.M. Sjulin, and M. Patterson. 1989. Postharvest storage characteristics and respiration rates in five cultivars of red raspberry. HortScience 24:980-982.

SAS Institute. 1989. SAS/STAT user's guide. version 6. vol. 2. 4th ed. SAS Inst., Cary, N.C.

Sjulin, T.M. and J. Robbins. 1987. Effects of maturity, harvest date, and storage time on post-harvest quality of red raspberry fruit. J. Amer. Soc. Hort. Sci. 112:481-487.

Smith, W.H. 1958. The harvesting, precooling, transport, and storage of strawberries and raspberries. Food Investigation Board. Misc. Paper 1058.

Smith, R.B. 1992. Controlled atmosphere storage of 'Redcoat' strawberry fruit. J. Amer. Soc. Hort. Sci. 117:260-264.

Song, Y., H.K. Kim, and K.L. Yam. 1992. Respiration rate of blueberry in modified atmosphere at various temperatures. J. Amer. Soc. Hort. Sci. 117:925-929.

Thornton, N.C. 1933. Carbon dioxide storage. III. The influence of carbon dioxide on the oxygen uptake by fruits and vegetables. Contrib. Boyce Thompson Inst. 5:371-402.

Winter, J.D., R.H. Landon, and W.H. Alderman. 1939. Use of carbon dioxide to retard the development of decay in strawberries and raspberries. Proc. Amer. Soc. Hort. Sci. 37:583-587.

Young, R.E., R.J. Romani, and J.B. Biale. 1962. Carbon dioxide effects on fruit respiration. II. Response of avocados, bananas and lemons. Plant Physiol. 37:416-422. 